\title{
Low Temperature Carburizing of Stainless Steels and the Development of Carbon Expanded Austenite*
} Niedrigtemperatur-Aufkohlung von nichtrostenden Stählen
und die Entwicklung von kohlenstoffexpandiertem Austenit

Low-temperature carburizing dramatically enhances the inherently low wear resistance of austenitic stainless steels due to the formation of a carbon-supersaturated solid solution, i.e. expanded austenite. The formation of expanded austenite from low-temperature carburizing has been intensively investigated. However, the influence of chemical composition of the stainless steel on the carburizing response has not received the same interest. This contribution addresses the effect of the chemical composition on low-temperature carburizing in terms of carbon solubility, decomposition of expanded austenite upon exceeding the solubility limit and the elasto-plastic accommodation of the carbon-induced lattice expansion. The results demonstrate that the carbon solubility increases with an increasing $\mathrm{Cr}$-equivalent and that higher $\mathrm{Cr}$ - and Ni-equivalents favor the formation of $\mathrm{Cr}$-based $\mathrm{M}_{7} \mathrm{C}_{3}$ over Fe-based Hägg $\left(\mathrm{M}_{5} \mathrm{C}_{2}\right)$ carbide.

Keywords: Expanded austenite, low-temperature carburizing, austenitic stainless steel, lattice rotation
Die Niedrigtemperatur-Aufkohlung verbessert die von Natur aus geringe Verschleißfestigkeit austenitischer nichtrostender Stähle durch die Bildung eines kohlenstoffgesättigten Mischkristalls, d.h. expandierten Austenits, erheblich. Die Bildung von expandiertem Austenit bei der Niedrigtemperatur-Aufkohlung wurde intensiv untersucht. Der Einfluss der chemischen Zusammensetzung des nichtrostenden Stahls auf die Aufkohlung hat jedoch nicht das gleiche Interesse gefunden. Dieser Beitrag befasst sich mit den Auswirkungen der chemischen Zusammensetzung auf die Niedrigtemperatur-Aufkohlung im Hinblick auf die Kohlenstofflöslichkeit, die Zersetzung des expandierten Austenits bei Überschreiten der Löslichkeitsgrenze und die elasto-plastische Kompensation der kohlenstoffinduzierten Gitterausdehnung. Die Ergebnisse zeigen, dass die Kohlenstofflöslichkeit mit steigendem $\mathrm{Cr}$-Gehalt zunimmt und dass höhere $\mathrm{Cr}$ - und Ni-Gehalte die Bildung von $\mathrm{M}_{7} \mathrm{C}_{3}$ auf $\mathrm{Cr}$-Basis gegenüber HäggKarbid $\left(\mathrm{M}_{5} \mathrm{C}_{2}\right)$ auf Fe-Basis begünstigen.

Schlïsselwörter: Expandierter Austenit, Niedrigtemperatur-Aufkohlung, austenitischer rostfreier Stahl, Gitterrotation

Authors/Autoren: Konstantin V. Werner, Dr. Thomas L. Christiansen, Prof. Dr. ir. Marcel A. J. Somers, Technical University of Denmark, Department of Mechanical Engineering, Produktionstorvet b. 425, DK 2800 Kongens Lyngby, Denmark, somers@mek.dtu.dk (Corresponding author/Kontakt) Dr. Honglong Che, Prof. Mingkai Lei, Surface Engineering Laboratory, School of Materials Science and Engineering, Dalian University of Technology, Dalian, People's Republic of China

HOW TO CITE THIS ARTICLE: K. V. Werner et al.: Low Temperature Carburizing of Stainless Steels and the Development of Carbon Expanded Austenite. HTM J. Heat Treatm. Mat. 77 (2022) 1, pp. 3-15 DOI:10.1515/htm-2022-0001

\section{Introduction}

Austenitic stainless steels exhibit exceptional corrosion resistance, but suffer at the same time from low wear resistance that limits their use in certain applications. Low-temperature surface harden-

\section{Einleitung}

Austenitische nichtrostende Stähle weisen eine außergewöhnliche Korrosionsbeständigkeit auf, leiden aber gleichzeitig unter einer geringen Verschleißfestigkeit, die ihre Verwendung in bestimmten

\footnotetext{
* Extensively reworked and extended version of a lecture held at European Conference on Heat Treatment, ECHT 2019, June 2-5, 2019, Bardolino, Italy 
ing, by either nitriding, carburizing or nitrocarburizing, has been shown to improve the wear resistance of austenitic stainless steels significantly due to the formation of a supersaturated solid solution $[1,2]$, i. e. expanded austenite, while maintaining or even improving their corrosion resistance [3-5]. Low-temperature nitriding and low-temperature carburizing are generally performed below $723 \mathrm{~K}$ and $823 \mathrm{~K}$ to avoid the formation of chromium nitrides and carbides, respectively [6]. In general, the dissolvable content of $\mathrm{N}$ in expanded austenite is higher (up to 38 at.\% [7]) than the dissolvable content of C (up to 17 at.\% [8]), due to the stronger affinity of $\mathrm{Cr}$ to $\mathrm{N}$ [9]. Strong nitride and carbide forming elements, such as $\mathrm{Ti}, \mathrm{V}, \mathrm{Nb}, \mathrm{Cr}$ and Mo have been shown to further enhance the solubility of $\mathrm{N}$ and $\mathrm{C}$ in expanded austenite $[10,11]$. The vast uptake of carbon and/or nitrogen results in a lattice expansion that scales linearly with the interstitial content $[12,13]$. As a consequence, compressive residual stresses in the order of several GPa's develop in the expanded austenite zone atop austenitic stainless steels [14-18]. The high interstitial content in expanded austenite provides solid solution strengthening, which is manifested as an increase in hardness to values beyond 1,000 HV [9]. Despite the significant solid solution strengthening, simulations have demonstrated that the built-up compressive residual stresses in expanded austenite eventually surpass the yield strength, implying that the lattice expansion is accommodated elasto-plastically for relatively high interstitial contents [19]. This is convincingly confirmed by experimental observations of surface roughening, lattice rotation and grain push-out for stainless steels after low-temperature nitriding [20-23]. For low-temperature carburizing, where a lower interstitial content is dissolved, the occurrence of elasto-plastic accommodation was first reported by Sun et al. [24] as well as Sun \& Chin [25] and was later suggested to explain the discrepancy between experimentally determined unconstrained lattice expansion and (elastic) residual stress [26]. Further, plasticity has been hinted at by the appearance of slip lines in secondary electron images after severe over-etching [27] and, indirectly, by the necessity to include plasticity to accurately predict the distribution of residual stresses over the expanded austenite zone from the carbon concentration profile [18]. Recent results on low-temperature carburizing of an equiatomic fcc $\mathrm{CoCrFeNi}$ high-entropy alloy demonstrated the occurrence of enhanced misorientation, albeit not quantitative, that could be a consequence of lattice rotation as a consequence of plastic accommodation of the lattice expansion in expanded austenite [28].

In the present contribution, the influence of the alloy composition on low-temperature carburizing of austenitic stainless steels is investigated with special focus on the $\mathrm{C}$-solubility and accommodation of the associated lattice expansion by plastic deformation. It will be shown that the chemical composition of austenitic stainless steels has a significant effect on the $\mathrm{C}$-uptake during low-temperature carburizing as well as on the formation of carbides upon
Anwendungen einschränkt. Es hat sich gezeigt, dass eine Oberflächenhärtung bei niedrigen Temperaturen, entweder durch Nitrieren, Aufkohlen oder Nitrocarburieren, die Verschleißfestigkeit von austenitischen nichtrostenden Stählen aufgrund der Bildung eines übersättigten Mischkristalls [1, 2], d. h. expandiertem Austenit, erheblich verbessert, während die Korrosionsbeständigkeit erhalten bleibt oder sogar verbessert wird [3-5]. Niedertemperatur-Nitrieren und Niedertemperatur-Aufkohlen werden im Allgemeinen unter $723 \mathrm{~K}$ bzw. $823 \mathrm{~K}$ durchgeführt, um die Bildung von Chromnitriden bzw. Karbiden zu vermeiden [6]. Im Allgemeinen ist der auflösbare Gehalt an N in expandiertem Austenit höher (bis zu 38 at.\% [7]) als der auflösbare Gehalt an C (bis zu 17 at.\% [8]), was auf die stärkere Affinität von $\mathrm{Cr}$ zu N zurückzuführen ist [9]. Starke nitrid- und karbidbildende Elemente wie $\mathrm{Ti}, \mathrm{V}, \mathrm{Nb}, \mathrm{Cr}$ und Mo erhöhen nachweislich die Löslichkeit von $\mathrm{N}$ und $\mathrm{C}$ in expandiertem Austenit $[10,11]$. Die umfangreiche Aufnahme von Kohlenstoff und/oder Stickstoff führt zu einer Gitterausdehnung, die linear mit dem interstitiellen Gehalt skaliert [12, 13]. Infolgedessen entwickeln sich in der expandierten Austenitzone von austenitischen nichtrostenden Stählen Druckeigenspannungen in der Größenordnung von mehreren GPa [14-18]. Der hohe Gehalt an Zwischengitteratomen in expandiertem Austenit führt zu einer Mischkristallverfestigung, die sich in einem Anstieg der Härte auf Werte von über 1.000 HV äußert [9]. Trotz der erheblichen Mischkristallverfestigung haben Simulationen gezeigt, dass die aufgebauten Druckeigenspannungen in expandiertem Austenit schließlich die Streckgrenze übersteigen, was bedeutet, dass die Gitterausdehnung bei relativ hohem Gehalt an Zwischengitteratomen elasto-plastisch kompensiert wird [19]. Dies wird durch experimentelle Beobachtungen von Oberflächenaufrauhung, Gitterrotation und Kornausdrücken bei nichtrostenden Stählen nach dem Niedertemperaturnitrieren überzeugend bestätigt [20-23]. Für das Niedertemperatur-Aufkohlen, bei dem ein geringerer Gehalt an Zwischengitteratomen erreicht wird, wurde das Auftreten von elastoplastischer Kompensation zuerst von Sun et al. [24] sowie Sun \& Chin [25] berichtet und später als Erklärung für die Diskrepanz zwischen experimentell ermittelter unbehinderter Gitterausdehnung und (elastischer) Eigenspannung vorgeschlagen [26]. Ferner wurde Plastizität durch das Auftreten von Gleitlinien in Sekundärelektronenbildern nach starkem Überätzen angedeutet [27] und indirekt durch die Notwendigkeit, Plastizität einzubeziehen, um die Verteilung der Eigenspannungen über der expandierten Austenitzone anhand des Kohlenstoffkonzentrationsprofils genau vorherzusagen [18]. Jüngste Ergebnisse zur Niedertemperatur-Aufkohlung einer äquiatomischen fcc $\mathrm{CoCrFeNi}$ Hochentropie-Legierung zeigten das Auftreten einer verstärkten Missorientierung, wenn auch nicht quantitativ, die eine Folge der Gitterrotation aufgrund der plastischen Anpassung der Gitterausdehnung in expandiertem Austenit sein könnte [28].

Im vorliegenden Beitrag wird der Einfluss der Legierungszusammensetzung auf die Niedrigtemperatur-Aufkohlung austenitischer nichtrostender Stähle mit besonderem Augenmerk auf die C-Löslichkeit und die Anpassung der damit verbundenen Gitterausdehnung durch plastische Verformung untersucht. Es wird gezeigt, dass die chemische Zusammensetzung von austenitischen nichtrostenden Stählen einen signifikanten Einfluss auf die 
exceeding the solubility limit and that elasto-plastic accommodation of the lattice expansion leads to pronounced and quantifiable lattice rotation.

\section{Experimental methods}

Two austenitic stainless steels with different $\mathrm{Cr}-, \mathrm{Ni}-, \mathrm{Mn}-$ and Mo-contents were selected. The chemical compositions, as determined by optical emission spectroscopy (OES), and the respective $\mathrm{Ni}$ - and Cr-equivalents, $\mathrm{Ni}_{\text {eq. }}$ and $\mathrm{Cr}_{\text {eq. }}$, are given in Table 1 .

Prior to low-temperature carburizing the specimens were ground and polished to a $1 \mu \mathrm{m}$ diamond finish. Carburizing was performed by the proprietary Kolsterising ${ }^{\otimes} 33$ process. According to [29] this process relies on an alkaline liquid bath that is flushed with a carbon-containing gas. Treatment time and temperature of the commercial Kolsterising ${ }^{\circledR}$ treatment are tailored such that AISI $316 \mathrm{~L}$ is provided with a $33 \mu \mathrm{m}$ thick case of carbon expanded austenite.

Light-optical microscopy (LOM) was performed on the cross sections of the as-carburized specimens with a Zeiss Axio Vert A.1 utilizing polarized light. The specimens were polished with $0.25 \mu \mathrm{m}$ diamond suspension and etched by immersion in Aqua Regia $\left(60 \mathrm{ml} \mathrm{HCl}, 20 \mathrm{ml} \mathrm{HNO}_{3}\right.$ ) and 2 drops of Dr. Vogel's Sparbeize at room temperature for 15 and 45 seconds, respectively.

Hardness-depth profiles were measured with Vickers micro-indentation on polished cross sections with a Future-Tech FM-700 hardness tester with Vickers diamond indenter, equipped with an Ikegami ICD-828PRXACDC 1/2" 530 TVL camera. The dwell time was set to $10 \mathrm{~s}$ and the test load was $5 \mathrm{~g}$. The given hardness values are averaged over three parallel indentation profiles.

The carbon concentration profiles in the expanded austenite zone were determined with GD-OES using a Horiba Jobin Yvon GD profiler 2 at a power of $40 \mathrm{~W}$ and a pressure of $1000 \mathrm{~Pa}$. The recorded intensity/chemical composition profiles were converted into depth resolved chemical composition profiles assuming a constant sputtering rate within expanded austenite. The sputter rate was determined from the crater depths measured with an Alicona InfiniteFocus R optical microscope. The GD-OES results were quantified
C-Aufnahme während der Niedrigtemperatur-Aufkohlung sowie auf die Bildung von Karbiden beim Überschreiten der Löslichkeitsgrenze hat und dass die elasto-plastische Kompensation der Gitterausdehnung zu einer ausgeprägten und quantifizierbaren Gitterrotation führt.

\section{Experimentelle Methoden}

Es wurden zwei austenitische nichtrostende Stähle mit unterschiedlichen $\mathrm{Cr}-$-, Ni-, Mn- und Mo-Gehalten ausgewählt. Die durch optische Emissionsspektroskopie (OES) bestimmten chemischen Zusammensetzungen und die entsprechenden $\mathrm{Ni}-$ und $\mathrm{Cr}-$ Äquivalente, $\mathrm{Ni}_{\text {eq. }}$ und $\mathrm{Cr}_{\text {eq. }}$, sind in Tabelle 1 angegeben.

Vor dem Aufkohlen bei niedriger Temperatur wurden die Proben geschliffen und abschließend mit einer $1 \mu \mathrm{m}$-Diamantsuspension poliert. Die Aufkohlung erfolgte nach dem patentrechtlich geschützten Kolsterising ${ }^{\circledR}$ 33-Verfahren. Nach [29] beruht dieses Verfahren auf einem alkalischen Flüssigkeitsbad, das mit einem kohlenstoffhaltigen Gas gespült wird. Behandlungszeit und -temperatur der kommerziellen Kolsterising ${ }^{\oplus}$-Behandlung sind so abgestimmt, dass AISI 316L mit einer $33 \mu \mathrm{m}$ dicken Randschicht aus kohlenstoffexpandiertem Austenit versehen wird.

Die Querschliffe der aufgekohlten Proben wurden mit einem Zeiss Axio Vert A.1 unter Verwendung von polarisiertem Licht lichtmikroskopisch (LOM) untersucht. Die Proben wurden mit einer $0,25 \mu \mathrm{m}$-Diamantsuspension poliert und durch Eintauchen in Aqua Regia ( $60 \mathrm{ml} \mathrm{HCl}, 20 \mathrm{ml} \mathrm{HNO}_{3}$ ) zusammen mit 2 Tropfen Dr. Vogel's Sparbeize bei Raumtemperatur für 15 bzw. 45 Sekunden geätzt.

Die Härteverläufe wurden mittels Vickers-Mikroindentation an polierten Querschnitten mit einem Future-Tech FM-700 Härteprüfgerät mit Vickers-Diamanteindringkörper gemessen, das mit einer Ikegami ICD-828PRXACDC 1/2" 530 TVL-Kamera ausgestattet war. Die Verweilzeit betrug $10 \mathrm{~s}$ und die Prüfkraft 5 g. Die angegebenen Härtewerte sind über drei parallele Profile gemittelt.

Die Kohlenstoffkonzentrationsprofile in der expandierten Austenitzone wurden mit GD-OES unter Verwendung eines Horiba Jobin Yvon GD profiler 2 bei einer Leistung von $40 \mathrm{~W}$ und einem Druck von 1000 Pa bestimmt. Die aufgezeichneten Intensitäts-/chemischen Zusammensetzungsprofile wurden in tiefenaufgelöste Profile der chemischen Zusammensetzung umgewandelt, indem eine konstante Sputterrate im expandierten Austenit angenommen wurde. Die Sputterrate wurde anhand der mit ei-

\begin{tabular}{|c|c|c|c|c|c|c|c|c|c|}
\hline & & \multicolumn{7}{|c|}{ Chemical composition in wt\% } \\
\hline Specimen & Alloy & $\mathrm{C}$ & $\mathrm{N}$ & $\mathrm{Cr}$ & $\mathrm{Ni}$ & $\mathrm{Mn}$ & $\mathrm{Mo}$ & $\mathrm{Cr}_{\text {eq. }}$ & $\mathrm{Ni}_{\text {eq. }}$ \\
\hline $\mathrm{A}$ & $1.4404 /$ X2CrNiMo17-12-2 & 0.03 & 0.07 & 17.72 & 11.18 & 1.51 & 2.11 & 20.7 & 14.9 \\
\hline $\mathrm{B}$ & $1.4565 /$ X2CrNiMnMoN 25-18-6-5 & 0.02 & 0.45 & 24.21 & 18.47 & 5.86 & 4.45 & 28.9 & 35.5 \\
\hline
\end{tabular}

Table 1. Chemical composition of the austenitic stainless steel specimens measured by OES prior to low-temperature carburizing. $\mathrm{Cr}_{\text {eq. }}$ and $\mathrm{Ni}_{\mathrm{eq}}$ are chromium and nickel equivalent, respectively

Tabelle 1. Chemische Zusammensetzung der Proben aus austenitischem rostfreiem Stahl, gemessen mit OES vor der Niedrigtemperaturaufkohlung. $\mathrm{Cr}_{\text {eq. }}$ und $\mathrm{Ni}_{\mathrm{eq}}$ sind Chrom- bzw. Nickeläquivalente 
using a set of austenitic stainless steel reference standards for the substitutional elements, while a layer of $\mathrm{Cr}_{23} \mathrm{C}_{6}$ on tool steel synthesized by thermo-reactive deposition and diffusion, was used as a standard for carbon.

X-ray diffraction was performed on a Bruker D8 Discover diffractometer equipped with Cr-radiation and operated in point focus at a voltage of $35 \mathrm{kV}$ and a current of $50 \mathrm{~mA}$. A $0.02 \mathrm{~mm}$ thick vanadium window was placed in the diffracted beam path to remove diffraction peaks originating from $\mathrm{Cr} \mathrm{K}_{\beta}$-radiation. Diffractograms were acquired in the range from $59-83^{\circ}-2 \theta$ at a counting time of 5 seconds per step and a step size of $0.04^{\circ}-2 \theta$. To avoid artifacts due to compositional and stress gradients in the expanded austenite zone, all measurements were performed at a constant information depth of $0.5 \mu \mathrm{m}$ by setting the grazing incidence angle $\alpha$ to $3^{\circ}$ in conjunction with a side inclination angle $\chi$ of $10.4^{\circ}$ as suggested in [17]. Approximately $3 \mu \mathrm{m}$ thick sublayers of expanded austenite were removed by polishing to investigate the influence of the C-content on the formation of carbides.

A cross-section sample of the carburized specimen B for investigation with transmission electron micrscopy (TEM) was taken out and further prepared until electron transparency with a FEI Helios G4 UX Dual Beam Focused Ion Beam system. Before lift out of a sample from the carburized case, Pt was deposited onto the specimen surface to mark the surface location and to avoid unintentional removal of the surface adjacent region to be investigated. A FEI Tecnai G2 TEM was operated at $200 \mathrm{kV}$ for imaging and selected area electron diffraction (SAED).

Electron backscatter diffraction (EBSD) was carried out on cross sections of the as-carburized specimens with a Zeiss Gemini Supra 35 field emission gun scanning electron microscope. To avoid edge rounding during polishing the samples were sheathed with a nickel electrodeposit. The specimens were manually ground and polished with colloidal silica as a final step. The SEM was operated at $15 \mathrm{kV}$, using an aperture size of $60 \mu \mathrm{m}$. The working distance was set to $13 \mathrm{~mm}$. Kikuchi patterns were acquired at a step size of $500 \mathrm{~nm}$ with a Nordlys detector over a $500 \times 100 \mu \mathrm{m}^{2}$ area, covering the expanded austenite zone as well as the substrate; data was analyzed using MTEX [30].

\section{Results and interpretation}

Light optical micrographs of the carburized specimens are depicted in Figure 1a and b. The expanded austenite zones of the two specimens appear featureless in comparison to the underlying base material, which is attributed to the more electrochemically nem Alicona InfiniteFocus R Lichtmikroskop gemessenen Kratertiefen bestimmt. Die GD-OES-Ergebnisse wurden mittels einer Reihe von Referenzstandards aus austenitischem rostfreiem Stahl für die Substitutionselemente quantifiziert, während eine Schicht aus $\mathrm{Cr}_{23} \mathrm{C}_{6}$ auf Werkzeugstahl, die durch thermoreaktive Abscheidung und Diffusion synthetisiert wurde, als Standard für Kohlenstoff verwendet wurde.

Die Röntgenbeugung wurde mit einem Bruker D8 Discover Diffraktometer durchgeführt, das mit Cr-Strahlung ausgestattet war und im Punktfokus bei einer Spannung von $35 \mathrm{kV}$ und einem Strom von $50 \mathrm{~mA}$ betrieben wurde. Ein 0,02 mm dickes Vanadium-Fenster wurde in den Beugungsstrahlengang eingesetzt, um Beugungspeaks zu entfernen, die von der $\mathrm{Cr}_{-} \mathrm{K}_{\beta}$-Strahlung stammen. Diffraktogramme wurden im Bereich von $59-83^{\circ}-2 \theta$ bei einer Zählzeit von 5 Sekunden pro Schritt und einer Schrittweite von $0,04^{\circ}-2 \theta$ aufgenommen. Um Artefakte aufgrund von Zusammensetzungs- und Spannungsgradienten in der expandierten Austenitzone $\mathrm{zu}$ vermeiden, wurden alle Messungen bei einer konstanten Informationstiefe von 0,5 $\mu$ m durchgeführt, indem der streifende Einfallswinkel $\alpha$ auf $3^{\circ}$ in Verbindung mit einem Seitenneigungswinkel $\chi$ von $10,4^{\circ}$ eingestellt wurde, wie in [17] vorgeschlagen. Ungefähr $3 \mu \mathrm{m}$ dicke Unterschichten aus expandiertem Austenit wurden durch Polieren entfernt, um den Einfluss des CGehalts auf die Bildung von Karbiden zu untersuchen.

Eine Querschnittsprobe der aufgekohlten Probe B für die Untersuchung mit der Transmissionselektronenmikroskopie (TEM) wurde entnommen und mit einem FEI Helios G4 UX Dual Beam Focused Ion Beam System bis zur Elektronentransparenz weiter präpariert. Vor der Entnahme der Probe aus aus der aufgekohlten Randschicht wurde Pt auf die Probenoberfläche aufgebracht, um die Lage der Oberfläche zu markieren und ein versehentliches Entfernen der an die Oberfläche angrenzenden zu untersuchenden Region zu vermeiden. Ein FEI Tecnai G2 TEM wurde bei $200 \mathrm{kV}$ für die Bildgebung und Elektronenbeugung (SAED) benutzt.

Die Elektronenrückstreubeugung (EBSD) wurde mit einem Zeiss Gemini Supra 35 Feldemissions-Rasterelektronenmikroskop an Querschliffen der aufgekohlten Proben durchgeführt. Um eine Kantenverrundung beim Polieren zu vermeiden, wurden die Proben mit einer elektrolytisch abgeschiedenen Nickelschicht ummantelt. Die Proben wurden manuell geschliffen und abschließend mit kolloidalem Siliziumdioxid poliert. Das REM wurde bei $15 \mathrm{kV}$ und einer Aperturgröße von $60 \mu \mathrm{m}$ betrieben. Der Arbeitsabstand wurde auf $13 \mathrm{~mm}$ eingestellt. Kikuchi-Muster wurden bei einer Schrittweite von $500 \mathrm{~nm}$ mit einem Nordlys-Detektor über einen Bereich von $500 \times 100 \mu \mathrm{m}^{2}$ aufgenommen, der sowohl die expandierte Austenitzone als auch das Substrat abdeckte; die Daten wurden mit MTEX [30] analysiert.

\section{Ergebnisse und Interpretation}

Die lichtmikroskopischen Schliffbilder der aufgekohlten Proben sind in Bild 1a und b dargestellt. Die expandierten Austenitzonen der beiden Proben erscheinen im Vergleich zum darunter liegenden Grundwerkstoff strukturlos, was auf das elektrochemisch ed- 

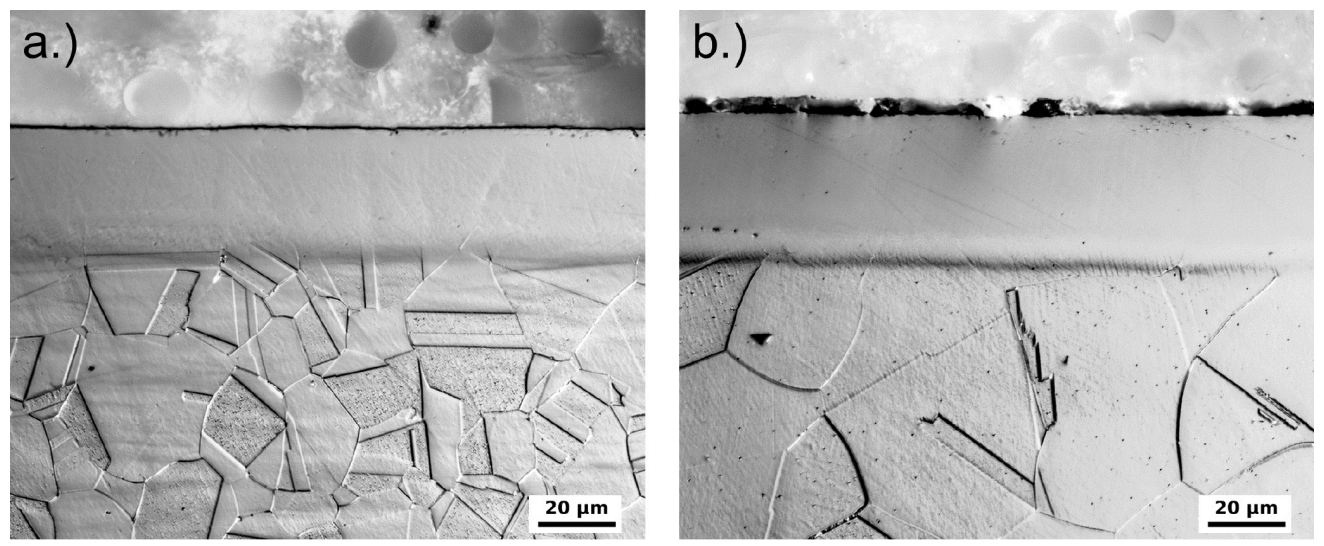

Fig. 1. Light-optical micrographs of the low-temperature carburized specimens after etching in Aqua Regia for 15 and 45 seconds at $25^{\circ} \mathrm{C}$, respectively: a.) specimen A - low-temperature carburized 1.4404 and b.) specimen B low-temperature carburized 1.4565

Bild 1. Lichtoptische Schliffbilder der tieftemperaturgekohlten Proben nach dem Ätzen in Aqua Regia für 15 bzw. 45 Sekunden bei $25^{\circ} \mathrm{C}$ : a.) Probe A - tieftemperaturgekohlter 1.4404 und b.) Probe $\mathrm{B}$ - tieftemperaturgekohlter 1.4565

noble performance of expanded austenite in the applied etchant, because of the uptake of large amounts of carbon.

The thickness of the formed expanded austenite zone amounts to $30 \pm 1 \mu \mathrm{m}$ for specimen A and to $39 \pm 1 \mu \mathrm{m}$ for specimen $\mathrm{B}$. The hardness-depth and carbon-depth profiles in Figure 2 confirm the case thicknesses determined by LOM and show a significantly higher $\mathrm{C}$-uptake for specimen $\mathrm{B}$, reaching a hardness of up to $1250 \mathrm{HV}$ close to the surface. Interestingly, the HV profile for specimen A reaches a plateau of $820 \mathrm{HV}$ at about $12 \mu \mathrm{m}$ from the surface, while for specimen B a plateau of about $1100 \mathrm{HV}$ is reached at a depth of approx. $18 \mu \mathrm{m}$. After the plateau is reached, on approaching the surface a further increase occurs for both specimens. On the other side, the $\mathrm{C}$-profiles in Figure $2 \mathrm{~b}$ do not reflect a similar plateau. Reaching a plateau hardness value implies that the further increase in carbon content close to the surface does not contribute to more solid solution strengthening. This could indicate the occurrence of plastic deformation or it could indicate that not all (additional) carbon is in solid solution. With respect to the plateau value, the hardness increase as observed closer to the surface suggests the formation of another carbon-containing phase.

Diffractograms of the non-carburized and as-carburized specimens are shown in Figure 3. Both materials exhibit solely fcc diffraction peaks in the non-carburized state. Upon low-temperature lere Verhalten des expandierten Austenits in dem verwendeten Ätzmittel aufgrund der Aufnahme großer Mengen an Kohlenstoff zurückzuführen ist.

Die Dicke der gebildeten expandierten Austenitzone beträgt $30 \pm 1 \mu \mathrm{m}$ für Probe A und $39 \pm 1 \mu \mathrm{m}$ für Probe B. Die Härteverläufe und Kohlenstoffgehaltsprofile in Bild 2 bestätigen die durch LOM ermittelten Randschichtdicken und zeigen eine deutlich höhere C-Aufnahme für Probe B, die nahe der Oberfläche eine Härte von bis zu $1250 \mathrm{HV}$ erreicht. Interessanterweise erreicht das HVProfil für Probe A ein Plateau von $820 \mathrm{HV}$ in etwa $12 \mu \mathrm{m}$ von der Oberfläche, während für Probe B ein Plateau von etwa $1100 \mathrm{HV}$ in einer Tiefe von ca. $18 \mu \mathrm{m}$ erreicht wird. Nach Erreichen des Plateaus kommt es bei beiden Proben bei Annäherung an die Oberfläche zu einem weiteren Anstieg. Auf der anderen Seite spiegeln die C-Profile in Bild 2b kein ähnliches Plateau wider. Das Erreichen eines Plateau-Härtewerts bedeutet, dass der weitere Anstieg des Kohlenstoffgehalts in Oberflächennähe nicht zu einer höheren Mischkristallverfestigung beiträgt. Dies könnte auf eine plastische Verformung hindeuten oder darauf, dass nicht der gesamte (zusätzliche) Kohlenstoff in fester Lösung vorliegt. Was den Plateauwert betrifft, so deutet der näher an der Oberfläche beobachtete Härteanstieg auf die Bildung einer weiteren kohlenstoffhaltigen Phase hin.

Die Diffraktogramme der nicht aufgekohlten und der aufgekohlten Proben sind in Bild 3 dargestellt. Beide Werkstoffe weisen im nicht aufgekohlten Zustand ausschließlich fcc-Beugungspeaks
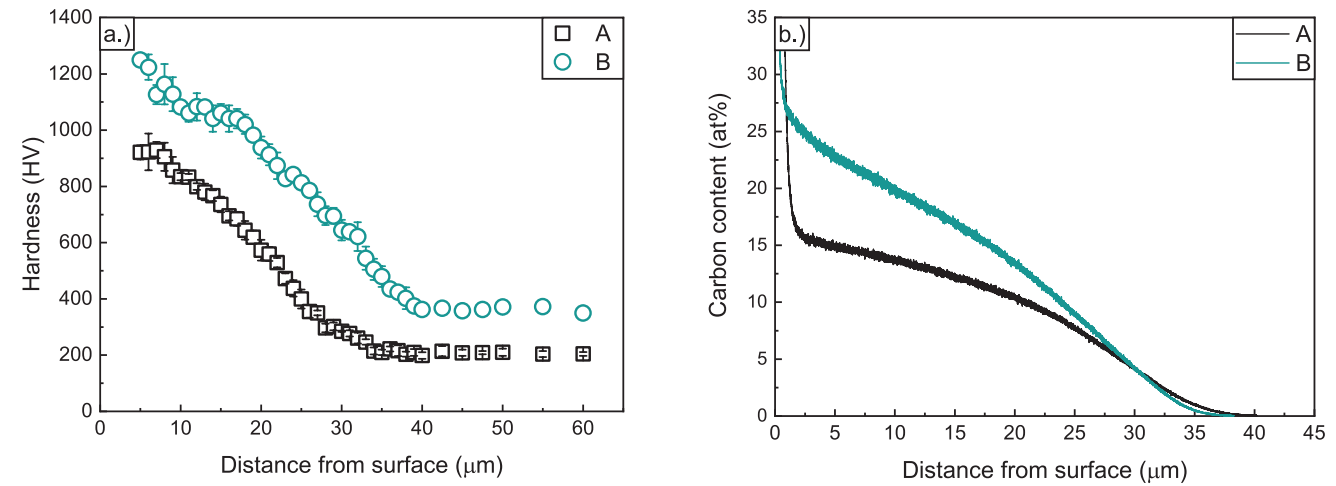

Fig. 2. a.) Vickers hardness profiles (HV0.05) for low-temperature carburized specimens $A$ and $B$, and b.) Carbon content profiles determined by GD-OES

Bild 2. a.) Vickers-Härteverläufe $(H V 0,05)$ für die bei niedriger Temperatur aufgekohlten Proben A und $B$ und $b$.) mittels GD-OES bestimmte Kohlenstoffgehaltsprofile 

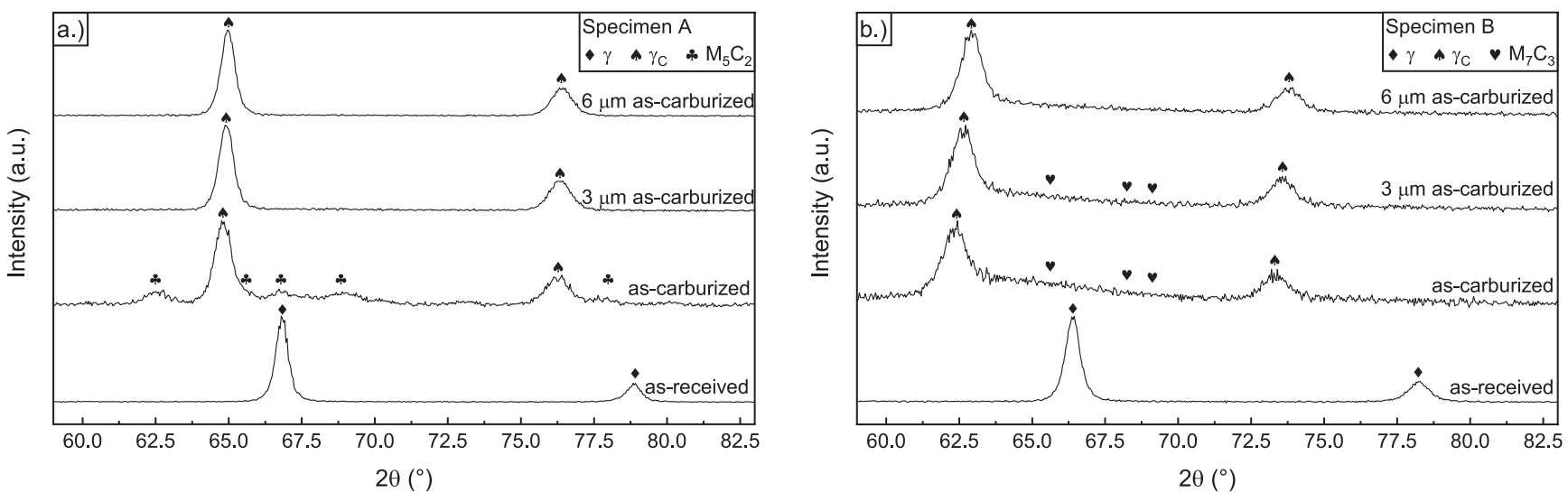

Fig. 3. Diffractograms of the as-received and the as-carburized specimen after removal of 0,3 and $6 \mu \mathrm{m}$. Diffractograms were normalized from 0 to 100 by the maximum intensity. a.) Specimen A, b.) Specimen B

Bild 3. Diffraktogramme der erhaltenen und der aufgekohlten Probe nach dem Abtragen von 0, 3 und $6 \mu \mathrm{m}$. Die Diffraktogramme wurden von 0 bis 100 auf die maximale Intensität normiert. a.) Probe A, b.) Probe B

carburizing, the observed fcc peaks are shifted to lower scattering angles, primarily due to the lattice expansion arising from the $\mathrm{C}$-uptake and to a lesser extent due to compressive residual stresses within the plane of the surface.

The significantly larger peak shift to lower Bragg angles for specimen $\mathrm{B}$ as compared to specimen $\mathrm{A}$ is in agreement with the difference in C-uptake (Figure 2b), confirming that more $\mathrm{C}$ is in solid solution in specimen $B$ than in specimen $A$. In addition to the peaks associated with carbon expanded austenite, the diffractogram of the as-carburized specimen A exhibits additional diffraction peaks corresponding to Fe-based Hägg carbide $\left(\mathrm{M}_{5} \mathrm{C}_{2}\right)$. This indicates that the solubility of carbon in expanded austenite is locally exceeded during low-temperature carburizing. This has been reported and investigated in more detail by others [31-34]. For the as-carburized specimen B, no distinct additional diffraction peaks appear in the diffractogram in Figure 3b. An anomalously long tail on the high $2 \theta$-side of the 111 reflection of expanded austenite beyond the peak position of the 111 reflection for carbon-free austenite, is incommensurate with the extent of the carbon concentration gradient over the shallow depth range probed under the applied X-ray diffraction geometry. This long tail is considered to be caused by the precipitation of nano-scale $\mathrm{Cr}$-based carbides, such as the orthorhombic $\omega-\mathrm{M}_{7} \mathrm{C}_{3}$, whose strongest reflections, as marked in the diffractogram, coincide with the angular range covered by the tail. Evidently, the identity of the carbides forming upon surpassing the solubility limit depends on the materials' chemical composition; high $\mathrm{Fe}$-contents (specimen A: $\mathrm{Fe}=67.83 \mathrm{wt} \%$ ) favor $\mathrm{M}_{5} \mathrm{C}_{2}$, while a reduction in the Fe-content and an increase in the $\mathrm{Cr}$ - and $\mathrm{Ni}$-contents (specimen $\mathrm{B}$ : $\mathrm{Fe}=46.54$ wt\%) favors the formation of Cr-based carbides. The absence of distinct diffraction peaks originating from the Cr-based carbides in specimen $B$ is explained from extensive overlap of broad peaks of nano-scale carbides. Selected area diffraction patterns from the highlighted region in the $\mathrm{BF}$ image of a lamella fibbed out auf. Nach dem Aufkohlen bei niedriger Temperatur verschieben sich die beobachteten fcc-Peaks zu niedrigeren Beugungswinkeln, was in erster Linie auf die Gitterausdehnung infolge der C-Aufnahme und in geringerem Maße auf Druckeigenspannungen innerhalb der Oberflächenebene zurückzuführen ist.

Die deutlich größere Peakverschiebung zu niedrigeren BraggWinkeln bei Probe B im Vergleich zu Probe A stimmt mit dem Unterschied in der C-Aufnahme überein (Bild 2b) und bestätigt, dass in Probe B mehr C im Mischkristall eingelagert ist als in Probe A. Zusätzlich zu den Peaks, die mit kohlenstoffexpandiertem Austenit assoziiert sind, zeigt das Diffraktogramm der aufgekohlten Probe A zusätzliche Beugungspeaks, die dem Fe-basierten Hägg-Karbid $\left(\mathrm{M}_{5} \mathrm{C}_{2}\right)$ entsprechen. Dies deutet darauf hin, dass die Löslichkeit des Kohlenstoffs im expandierten Austenit während der Niedrigtemperatur-Aufkohlung lokal überschritten wird. Dies wurde bereits von anderen Forschern berichtet und genauer untersucht [31-34]. Bei der aufgekohlten Probe B erscheinen im Diffraktogramm in Bild $3 \mathrm{~b}$ keine deutlichen zusätzlichen Beugungspeaks. Ein anomal langer Schweif auf der hohen 20-Seite der 111-Reflexion von expandiertem Austenit, der über die Spitzenposition der 111-Reflexion für kohlenstofffreien Austenit hinausgeht, ist unvereinbar mit dem Ausmaß des Kohlenstoffkonzentrationsgradienten über den flachen Tiefenbereich, der unter der angewandten Röntgenbeugungsgeometrie untersucht wurde. Es ist davon auszugehen, dass dieser lange Schweif durch die Ausscheidung nanokristalliner Karbide auf Cr-Basis verursacht wird, wie z. B. das orthorhombische $\omega-\mathrm{M}_{7} \mathrm{C}_{3}$, dessen stärkste Reflexe, wie im Diffraktogramm markiert, mit dem von dem Schweif abgedeckten Winkelbereich zusammenfallen. Offensichtlich hängt die Identität der Karbide, die sich beim Überschreiten der Löslichkeitsgrenze bilden, von der chemischen $\mathrm{Zu}$ sammensetzung der Materialien ab; hohe Fe-Gehalte (Probe A: $\mathrm{Fe}=67,83$ Gew. $-\%$ ) begünstigen $\mathrm{M}_{5} \mathrm{C}_{2}$, während eine Verringerung des Fe-Gehalts und eine Erhöhung der Cr- und Ni-Gehalte (Probe B: $\mathrm{Fe}=46,54$ Gew.-\%) die Bildung von Karbiden auf Cr-Basis begünstigt. Das Fehlen ausgeprägter Beugungspeaks, die von den $\mathrm{Cr}-$ 
perpendicular from the as-carburized surface of specimen B in Figure $4 \mathrm{a}$, confirm the XRD-based hypothesis that the expanded austenite zone contains carbides in addition to expanded austenite (Figure $4 \mathrm{~b}$ ). The SAED pattern of the carbide containing region in Figure 4a given in Figure $4 \mathrm{c}$ indicates that the elongated needle shaped particles are indeed $\omega-\mathrm{M}_{7} \mathrm{C}_{3}$. The SAED in Figure $4 \mathrm{~d}$ shows that $(200)_{\omega}||\{11 \overline{1}\}_{\gamma} \wedge[01 \overline{3}]_{\omega}||\langle 1 \overline{1} 0\rangle_{\gamma}$, which is consistent with the orientation relation inferred in [32] .

The image quality map (IQM) of a cross-section of the as-carburized specimen A in Figure 5a exhibits dark linear features in the near-surface zone of certain grains (see Figure $5 b$ ). These are either slip lines, or deformation twins, implying that plastic accommodation of the lattice expansion has occurred. Misorientation profiles along the highlighted lines in the corresponding orientation image map (Figure 5c) are given in Figure 5d and show that the lattice in some grains rotates due to plastic deformation. The extent and the direction of the lattice rotation (Figure 5e) depend on the initial grain orientation and the number of (consecutively or simultaneously) activated slip planes. Lattice rotations are observed to a depth of $12-15 \mu \mathrm{m}$, i. e. the depth where the HV plateau is reached (Fig. 2a). This corresponds to a carbon content threshold of approx. 13 at.\% (Fig. 2b) that has to be surpassed before the residual stresses that would arise on full elastic accommodation of the lattice expansion outweigh the yield strength under biaxial compression that is effectively augmented by solid solution strengthening.
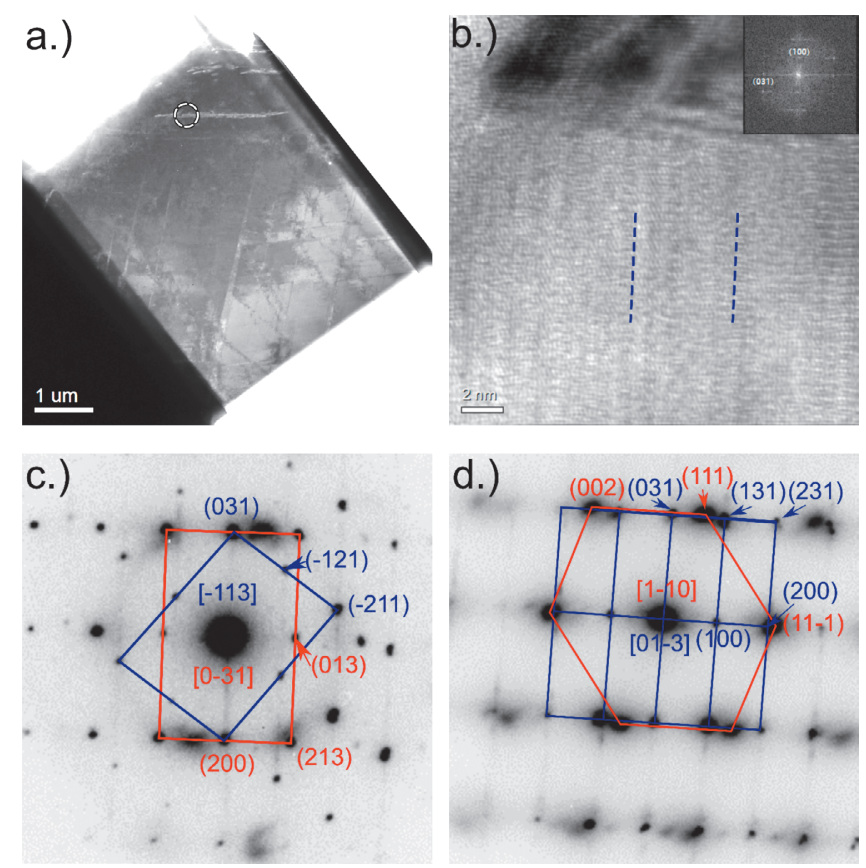

basierten Karbiden in Probe B stammen, erklärt sich aus der weitgehenden Überlappung breiter Peaks der nanokristallinen Karbide. Ausgewählte Beugungsbilder aus dem hervorgehobenen Bereich im BF-Bild einer Lamelle, die senkrecht von der aufgekohlten Oberfläche der Probe B mittels Ionenfeinstrahl herausgetrennt ist (Bild 4a), bestätigen die auf XRD basierende Hypothese, dass die expandierte Austenitzone zusätzlich zum expandierten Austenit Karbide enthält (Bild 4b). Das SAED-Muster des karbidhaltigen Bereichs aus Bild 4a in Bild 4c zeigt, dass es sich bei den länglichen, nadelförmigen Partikeln tatsächlich um $\omega-\mathrm{M}_{7} \mathrm{C}_{3}$ handelt. Das SAED-Muster in Bild $4 \mathrm{~d}$ veranschaulicht, dass $(200)_{\omega}||\{11 \overline{1}\}_{\gamma} \wedge[01 \overline{3}]_{\omega}||\langle 1 \overline{1} 0\rangle_{\gamma}$, was mit der in [32] ermittelten Orientierungsbeziehung übereinstimmt.

Die Patternqualitäts-Map (IQM) eines Querschliffs der aufgekohlten Probe A in Bild 5a zeigt dunkle lineare Merkmale in der oberflächennahen Zone bestimmter Körner (siehe Bild 5b). Dabei handelt es sich entweder um Gleitlinien oder Verformungszwillinge, was bedeutet, dass eine plastische Anpassung der Gitterausdehnung stattgefunden hat. Missorientierungsprofile entlang der hervorgehobenen Linien in der entsprechenden Orientierungs-Map (Bild 5c) sind in Bild 5d dargestellt und zeigen, dass sich das Gitter in einigen Körnern aufgrund der plastischen Verformung dreht. Das Ausmaß und die Richtung der Gitterdrehung (Bild 5e) hängen von der ursprünglichen Kornorientierung ab. Das Ausmaß und die Richtung der Gitterdrehung (Bild 5e) hängen von der ursprünglichen Kornorientierung und der Anzahl der (nacheinander oder gleichzeitig) aktivierten Gleitebenen ab. Gitterdrehungen werden bis zu einer Tiefe von 12-15 $\mu \mathrm{m}$ beobachtet, d. h. der Tiefe, in der das HV-Plateau erreicht wird (Bild 2a). Dies entspricht einem Schwellenwert für den Kohlenstoffgehalt von ca. 13 at.\% (Bild 2b), der überschritten werden muss, bevor die Eigenspannungen, die bei vollständiger elastischer Anpassung der Gitterausdehnung auftreten würden, die Streckgrenze unter biaxialer Kompression übersteigen, die durch die Mischkristallverfestigung wirksam erhöht wird.

Fig. 4. a.) Bright field image of a lamella fibbed out perpendicular to the as-carburized surface of specimen B; b) High Resolution Electron Microscopy of carbide particle, showing that (310) planes are faulted (stacking faults), consequently fast Fourier transform of the lattice image in the insert shows intensity lines along [031]; c.)/d.). SAED patterns of carbon expanded austenite and carbide corresponding to the highlighted region in the $\mathrm{BF}$ image for different beam directions (tilt angles). The faint intensity along the [031] direction is caused by faulting on (031]) planes (see dashed lines in b.))

Bild 4. a.) Hellfeldbild einer Lamelle, die senkrecht zur aufgekohlten Oberfläche der Probe B herausgetrennt ist; b.) Hochauflösende Elektronenmikroskopie des Karbidpartikels, die zeigt, dass die (310)-Ebenen gefaltet sind (Stapelfehler), daher zeigt die schnelle Fourier-Transformation des Gitterbildes im Einsatz Intensitätslinien entlang [031]; c.)/d.). SAED-Muster von kohlenstoffexpandiertem Austenit und Karbid entsprechend dem hervorgehobenen Bereich im BF-Bild für verschiedene Strahlrichtungen (Neigungswinkel). Die schwache Intensität entlang der [031]-Richtung wird durch Verwerfungen auf den (031]-Ebenen verursacht (siehe gestrichelte Linien in b.)) 
Fig. 5. a.) Image quality map (IQM); b.) detail view of the highlighted area in a.); c.) Orientation image map (OIM) with lines along which misorientation profiles have been determined (coloring of various orientations with respect to the surface normal as shown in the legend in d.); d.) Misorientation profiles along the lines highlighted in the OIM and e.) lattice rotation along the highlighted lines shown in the standard stereographic triangle for the as-carburized specimen $\mathrm{A}$. The position of the transition from expanded austenite to austenite is given by the black dashed line in c.)

Bild 5. a.) Patternqualitäts-Map (IQM); b.) Detailansicht des hervorgehobenen Bereichs in a.); c.) Orientierungs-Map (OIM) mit Linien, entlang derer Missorientierungsprofile bestimmt wurden (Einfärbung verschiedener Orientierungen in Bezug auf die Oberflächennormale wie in der Legende in d.); d.) Missorientierungsprofile entlang der im OIM hervorgehobenen Linien und e.) Gitterdrehung entlang der hervorgehobenen Linien im stereografischen Standarddreieck für die Probe A im aufgekohlten Zustand.

Die Position des Übergangs von expandiertem Austenit zu Austenit ist durch die schwarze gestrichelte Linie in c.) angegeben
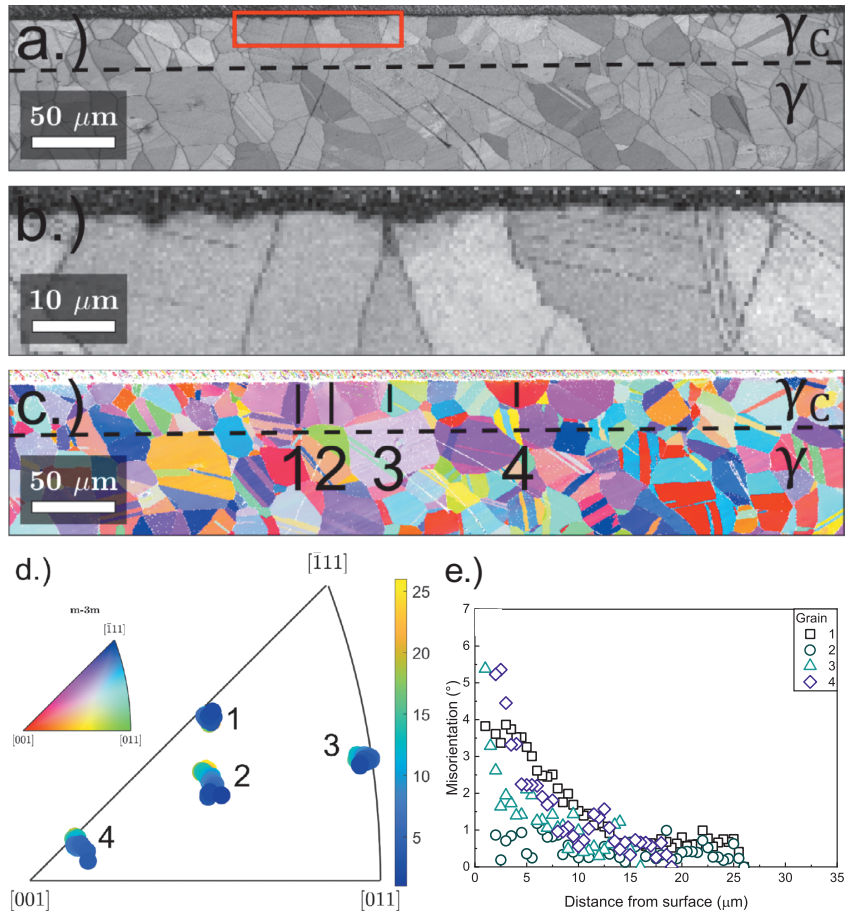

e.)

Die IQM der aufgekohlten Probe B zeigt im oberflächennahen Bereich eine deutlich höhere Dichte an dunklen linearen Merkmalen als im Fall von Probe A. Diese Merkmale sind eindeutig das Ergebnis einer stärkeren plastischen Verformung. Bestimmte Körner weisen Gleitlinien in verschiedenen Richtungen auf, was bedeutet, dass mehr als ein Gleitsystem aktiviert wurde. Eine stärkere plastische Verformung geht zwangsläufig mit einer schlechteren Indizierung der lokalen Orientierungen einher, wie die weißen Punkte (nicht indizierte Pixel) in Bild 6c zeigen.

Die in Bild 6e gezeigten Missorientierungsprofile, die entlang der hervorgehobenen Linien im OIM in Bild $6 c$ gemessen wurden, erreichen im Vergleich zu denen der Probe A höhere Werte, was eine stärkere plastische Verformung im Zusammenhang mit der deutlich höheren C-Aufnahme der Probe B bestätigt.

Offensichtlich ist die Gitterrotation im expandierten Austenit der Probe B nicht auf eine oberflächennahe C-reiche Schicht beschränkt, sondern beginnt bei den Körnern 2 und 3 direkt beim Übergang vom unbehandelten Grundwerkstoff in die Zone des expandierten Austenits. Die meiste Rotation wird jedoch in den äußeren $20 \mu \mathrm{m}$ beobachtet, was dem Beginn des Härteplateaus in Bild 2a entspricht.

\section{Diskussion}

\subsection{Einfluss der Legierungszusammensetzung auf die Kohlenstofflöslichkeit in expandiertem Austenit}

Die Beobachtung, dass ein höherer Gehalt an starken karbidbildenden Elementen die Kohlenstofflöslichkeit in kohlenstoffexpandiertem Austenit erhöht, ist im Einklang mit früheren Erkenntnissen 

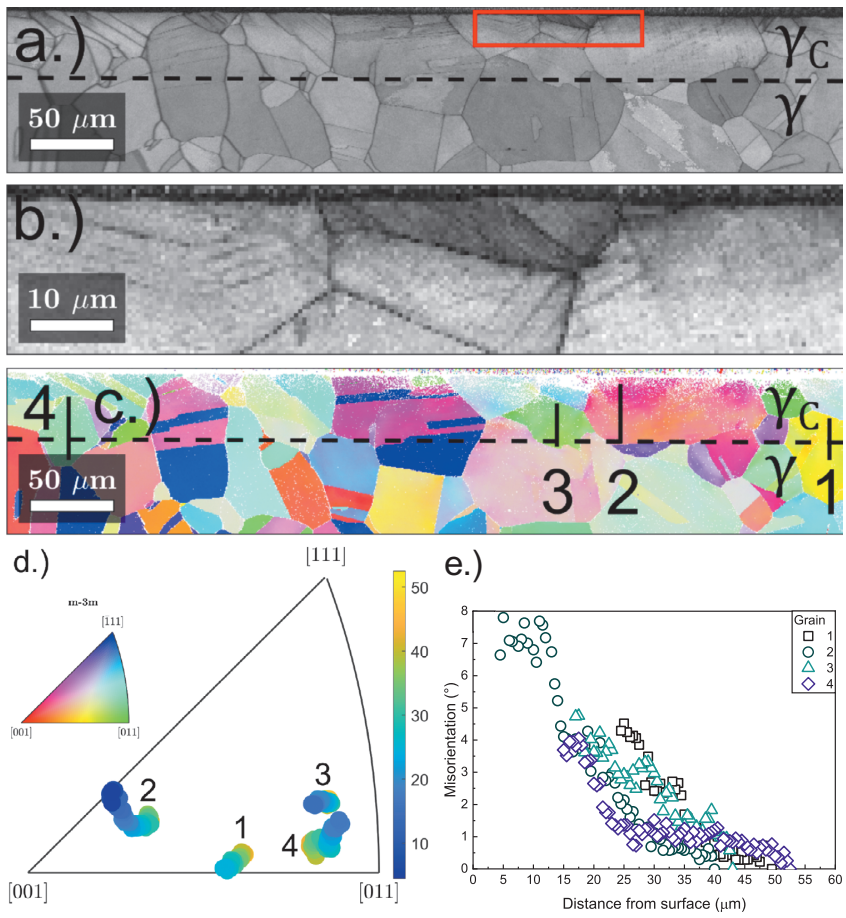

ed austenite as well as with observations on the effect of strong nitride-formers on the $\mathrm{N}$-solubility in nitrogen expanded austenite $[10,11]$.

The observation of an increase in the depth of the expanded austenite zone with increasing $\mathrm{Cr}$-content seems counterintuitive. A higher content of $\mathrm{Cr}$ and Mo in specimen $\mathrm{B}$ would be expected to lead to more trapping (by short range order with $\mathrm{Cr}$ ) of arriving C-atoms, and a concomitantly thinner expanded austenite zone than in specimen A. This is deduced by adopting Wagner's equation, originally derived for internal oxidation, which shows that the thickness of the case, $\xi$, is inversely proportional to the concentration of the element that traps the diffusing species, $c_{M}$ (cf. [36] for a derivation and an application to nitriding):

$\xi^{2}=2 D_{c} \frac{c_{c}^{s}}{n c_{M}} t+K$

where $\mathrm{D}_{\mathrm{c}}$ is the diffusivity of carbon in expanded austenite, $c_{c}^{s}$ is the concentration of non-trapped carbon in expanded austenite at the surface, $\mathrm{n}$ is the number of trapped carbon atoms per atom of the trapping element $\mathrm{M}, \mathrm{t}$ is time and $\mathrm{K}$ is an arbitrary integration constant that can account for an incubation time. Apparently, the effect of a higher content of trapping elements, $c_{M}$, on the case depth is (over)compensated by a higher lattice solubility of carbon and/or a larger diffusion coefficient of carbon. Indeed, the combination of XRD and GD-OES results shows convincingly that more carbon is dissolved in expanded austenite developed on specimen B. Realizing that the diffusivity of carbon (as nitrogen), increases with the interstitial content [37], for the composition range under
Fig. 6. a.) Image quality map (IQM); b.) detail view of the highlighted area in a.); c.) Orientation image map (OIM) with lines along which misorientation profiles have been determined; d.) Lattice rotation along the highlighted lines shown in the standard stereographic projection for the as-carburized specimen $B$ and e.) misorientation profiles along the lines highlighted in the OIM.The position of the transition from expanded austenite to austenite is given by the black dashed line in c.)

Bild 6. a.) Patternqualitäts-Map (IQM); b.) Detailansicht des hervorgehobenen Bereichs in a.); c.) Orientierungs-Map (OIM) mit Linien, entlang derer Missorientierungsprofile bestimmt wurden, d.) Gitterdrehung entlang der hervorgehobenen Linien, dargestellt in der stereographischen Standardprojektion für die ungehärtete Probe $B$ und e.) Missorientierungsprofile entlang der im OIM hervorgehobenen Linien. Die Position des Übergangs von expandiertem Austenit zu Austenit ist durch die schwarze gestrichelte Linie in c.) angegeben

[35] über kohlenstoffexpandiertem Austenit sowie mit Beobachtungen über die Auswirkung von starken Nitridbildnern auf die NLöslichkeit in stickstoffexpandiertem Austenit $[10,11]$.

Die Beobachtung, dass die Tiefe der expandierten Austenitzone mit zunehmendem Cr-Gehalt zunimmt, erscheint kontraintuitiv. Man würde erwarten, dass ein höherer Cr- und Mo-Gehalt in Probe B zu einer stärkeren Bindung von ankommenden C-Atomen (durch Kurzstreckenordnung mit $\mathrm{Cr}$ ) und damit zu einer dünneren expandierten Austenitzone als in Probe A führt. Dies ergibt sich aus der ursprünglich für die innere Oxidation abgeleiteten Gleichung von Wagner, die zeigt, dass die Dicke der Randschicht $\xi$, umgekehrt proportional zur Konzentration des Elements ist, das die diffundierende Spezies einfängt, $c_{M}$ (vgl. [36] für eine Herleitung und eine Anwendung auf das Nitrieren):

$\xi^{2}=2 D_{c} \frac{c_{c}^{s}}{n c_{M}} t+K$

wobei $\mathrm{D}_{\mathrm{c}}$ die Diffusivität des Kohlenstoffs im expandierten Austenit, $c_{c}^{s}$ die Konzentration des nicht eingeschlossenen Kohlenstoffs im expandierten Austenit an der Oberfläche, n die Anzahl der eingeschlossenen Kohlenstoffatome pro Atom des einschlieBenden Elements $\mathrm{M}, \mathrm{t}$ die Zeit und K eine Integrationskonstante ist, die eine Inkubationszeit berücksichtigen kann. Offenbar wird die Auswirkung eines höheren Gehalts an Einschlusselementen, $c_{\mathrm{M}}$, auf die Randschichtdicke durch eine höhere Gitterlöslichkeit des Kohlenstoffs und/oder einen größeren Diffusionskoeffizienten des Kohlenstoffs (über)kompensiert. In der Tat zeigt die Kombination von XRD- und GD-OES-Ergebnissen überzeugend, dass mehr Kohlenstoff im expandierten Austenit 
investigation, it can be rationalized that a deeper expanded austenite case develops for the higher alloyed stainless steel. In addition to this, Christiansen et al. [38] have shown that neglecting the influence of a stress gradient on the driving force for diffusion of interstitial elements in expanded austenite can result in an underestimation of the diffusion rate during low-temperature surface hardening. Considering the significantly steeper carbon-profile for specimen B in Figure $2 b$, a steeper gradient in compressive residual stresses will develop, which further augments the inward flux of carbon atoms in expanded austenite (note that this effect is not accounted for by Eq. 1).

\subsection{Influence of alloy composition on carbide formation upon surpassing of the carbon solubility in expanded austenite}

The XRD and TEM results indicate a distinct difference between the carbides that precipitate in the near-surface region depending on the materials composition. Christiansen et al. [8] pointed out that Hägg-carbide forms in low-temperature gas carburized AISI $316 \mathrm{~L}$, when the solubility limit of carbon in expanded austenite is exceeded and partitioning of substitutional elements is hindered by the relatively low temperature. Energy-filtered TEM revealed that the formation of Hägg-carbide does involve a redistribution of substitutional elements [31]. In this respect it should be realized that a higher carburizing temperature was applied in [31] than in [8]. Hägg-carbide is metastable and tends to transform into $\mathrm{M}_{7} \mathrm{C}_{3}$, which involves the redistribution of $\mathrm{Ni}$ [32] if it is kept at elevated temperatures for a prolonged time. The identity of the carbide that eventually forms, is governed by the precipitation kinetics. High Ni-contents suppress the formation of Hägg carbide and favor the formation of other carbides [33,34], consistent with the observed influence of the alloy composition on the carbide formation in the present study. Evidently, in combination with the relatively high $\mathrm{Cr}$-content, the formation of the thermodynamically more stable Cr-based carbide $\mathrm{M}_{7} \mathrm{C}_{3}$ is favoured over the kinetically stabilized Hägg-carbide. It is noted that $\omega-\mathrm{M}_{7} \mathrm{C}_{3}$ develops along $\{111\}_{\gamma}$, which are the slip planes in fcc. Accordingly, it is suggested that the larger plastic strain in specimen B (cf. Fig. 6d) contributes to promote $\mathrm{M}_{7} \mathrm{C}_{3}$ formation. Since the host lattices of metal atoms in $\gamma$ and $\omega-\mathrm{M}_{7} \mathrm{C}_{3}$ require only small changes to transform into each other [32], it is further suggested that a shearing operation accomplishes the transformation along the slip, and thus habit, planes in fcc. der Probe B gelöst ist. Wenn man bedenkt, dass die Diffusivität von Kohlenstoff, als auch die von Stickstoff mit dem interstitiellen Gehalt [37] für den untersuchten Zusammensetzungsbereich zunimmt, kann man davon ausgehen, dass sich eine tiefere expandierte Austenitzone für den höher legierten nichtrostenden Stahl entwickelt. Darüber hinaus haben Christiansen et al. [38] gezeigt, dass die Vernachlässigung des Einflusses eines Spannungsgradienten auf die treibende Kraft für die Diffusion von interstitiellen Elementen in expandiertem Austenit zu einer Unterschätzung der Diffusionsrate während der Niedrigtemperatur-Oberflächenhärtung führen kann. In Anbetracht des deutlich steileren Kohlenstoffprofils der Probe B in Bild 2b wird sich ein steilerer Gradient der Druckeigenspannungen entwickeln, der den Zustrom von Kohlenstoffatomen in den expandierten Austenit weiter verstärkt (dieser Effekt wird in Gleichung 1 nicht berücksichtigt).

\subsection{Einfluss der Legierungszusammensetzung auf die Karbidbildung beim Überschreiten der Kohlenstofflöslichkeit im expandierten Austenit}

Die XRD- und TEM-Ergebnisse weisen auf einen deutlichen Unterschied zwischen den Karbiden hin, die sich im oberflächennahen Bereich in Abhängigkeit von der Werkstoffzusammensetzung ausscheiden. Christiansen et al. [8] wiesen darauf hin, dass sich Hägg-Karbid in gasaufgekohltem AISI 316L bei niedriger Temperatur bildet, wenn die Löslichkeitsgrenze des Kohlenstoffs im expandierten Austenit überschritten wird und die Verteilung der Substitutionselemente durch die relativ niedrige Temperatur behindert wird. Energiegefilterte TEM-Untersuchungen ergaben, dass die Bildung von Hägg-Karbid mit einer Umverteilung von Substitutionselementen einhergeht [31]. In diesem Zusammenhang sollte beachtet werden, dass in [31] eine höhere Aufkohlungstemperatur als in [8] angewendet wurde. Hägg-Karbid ist metastabil und neigt dazu, sich in $\mathrm{M}_{7} \mathrm{C}_{3}$ umzuwandeln, was mit einer Umverteilung von $\mathrm{Ni}$ verbunden ist [32], wenn es über einen längeren Zeitraum bei erhöhten Temperaturen gehalten wird. Die Identität des Karbids, das sich schließlich bildet, wird durch die Ausscheidungskinetik bestimmt. Hohe Ni-Gehalte unterdrücken die Bildung von HäggKarbid und begünstigen die Bildung anderer Karbide [33, 34], was mit dem beobachteten Einfluss der Legierungszusammensetzung auf die Karbidbildung in der vorliegenden Studie übereinstimmt. Offensichtlich wird in Kombination mit dem relativ hohen $\mathrm{Cr}$-Gehalt die Bildung des thermodynamisch stabileren Cr-basierten Karbids $\mathrm{M}_{7} \mathrm{C}_{3}$ gegenüber dem kinetisch stabilisierten Hägg-Karbid begünstigt. Es ist festzustellen, dass sich $\omega-\mathrm{M}_{7} \mathrm{C}_{3}$ entlang der $\{111\}_{\gamma}$ entwickelt, die die Gleitebenen in fcc sind. Dementsprechend wird vermutet, dass die größere plastische Dehnung in Probe B (vgl. Bild 6d) zur Förderung der $\mathrm{M}_{7} \mathrm{C}_{3}-$ Bildung beiträgt. $\mathrm{Da}$ die Wirtsgitter der Metallatome in und $\omega-\mathrm{M}_{7} \mathrm{C}_{3}$ nur kleine Änderungen benötigen, um sich ineinander umzuwandeln [32], wird ferner angenommen, dass eine Scherung die Umwandlung entlang der Gleitebenen und damit der Habitusebenen in fcc bewirkt. 


\subsection{Plastic accommodation of compressive residual stresses}

The presented EBSD results indicate clearly that the carbon-induced lattice expansion is accommodated partially by plastic deformation as is manifested by lattice rotation and an increasing misorientation towards the surface. The reason that earlier studies on low-temperature carburizing of austenitic stainless steels did not report the occurrence of lattice rotation, could be a relatively low C-content in expanded austenite or because it was simply overlooked. Both the degree and the direction of the lattice rotation depend significantly on the original grain orientation, which is consistent with earlier findings by Templier et al. [21] and Stinville et al. [39] for plasma nitriding and later for gaseous nitriding in [22]. The occurrence of elasto-plastic accommodation of the lattice expansion has implications for the hardness profile and residual stress-depth profile that develop, as well as for the fatigue performance. Further, the numerical simulation of the carburizing process to predict composition, residual stress, extent of plastic deformation in relation to the process parameters, needs to take these factors into account. This complicated interplay of thermochemical treatment and residual stress was earlier successfully demonstrated for gaseous nitriding $[19,40]$.

\section{Conclusions}

The presented results show that the chemical composition of stainless steel has an important influence on the response during low-temperature carburizing. Increasing amounts of strong carbide formers enhance the carbon solubility and concomitantly the hardness in the expanded austenite zone. In addition to its influence on the C-uptake, the chemical composition has an influence on which carbides form once the $\mathrm{C}$-solubility in expanded austenite is exceeded. A high Ni-content in combination with a high $\mathrm{Cr}$-content prevents the formation of Fe-based Hägg carbide, $\mathrm{M}_{5} \mathrm{C}_{2}$, and favors the formation of more thermodynamically stable Cr-based carbide $\omega-\mathrm{M}_{7} \mathrm{C}_{3}$. Furthermore, a higher content of alloying elements that trap interstitials, appears to promote a deeper expanded austenite case depth during low-temperature carburizing. Similar to low-temperature nitrided austenitic stainless steels, the interstitial-induced lattice expansion is accommodated elasto-plastically, as manifested by slip lines and lattice rotation in the near surface region of the expanded austenite case. More plastic deformation occurs for a higher carbon content, which may contribute to promoting $\omega-\mathrm{M}_{7} \mathrm{C}_{3}$ over $\mathrm{M}_{5} \mathrm{C}_{2}$.

\subsection{Plastische Kompensation von Druckeigenspannungen}

Die vorgestellten EBSD-Ergebnisse zeigen deutlich, dass die kohlenstoffinduzierte Gitterausdehnung teilweise durch plastische Verformung kompensiert wird, was sich in einer Gitterrotation und einer zunehmenden Missorientierung zur Oberfläche hin äußert. Der Grund dafür, dass in früheren Studien über die Niedrigtemperatur-Aufkohlung von austenitischen nichtrostenden Stählen nicht über das Auftreten von Gitterrotation berichtet wurde, könnte zum einen ein relativ niedriger C-Gehalt im expandierten Austenit sein und zum anderen könnte die Gitterrotation einfach übersehen worden sein. Sowohl das Ausmaß als auch die Richtung der Gitterrotation hängen wesentlich von der ursprünglichen Kornorientierung ab, was mit früheren Erkenntnissen von Templier et al. [21] und Stinville et al. [39] für das Plasmanitrieren und später für das gasförmige Nitrieren in [22] übereinstimmt. Das Auftreten einer elasto-plastischen Kompensation der Gitterausdehnung hat Auswirkungen auf das sich entwickelnde Härteprofil und das Eigenspannungstiefenprofil sowie auf die Dauerfestigkeit. Bei der numerischen Simulation des Aufkohlungsprozesses zur Vorhersage der Zusammensetzung, der Eigenspannungen und des Ausmaßes der plastischen Verformung in Abhängigkeit von den Prozessparametern müssen diese Faktoren ebenfalls berücksichtigt werden. Dieses komplizierte Zusammenspiel von thermochemischer Behandlung und Eigenspannung wurde bereits für das Gasnitrieren erfolgreich nachgewiesen $[19,40]$.

\section{Schlussfolgerungen}

Die vorgestellten Ergebnisse zeigen, dass die chemische Zusammensetzung des nichtrostenden Stahls einen wichtigen Einfluss auf das Verhalten bei der Niedrigtemperatur-Aufkohlung hat. Ein zunehmender Anteil an starken Karbidbildnern erhöht die Kohlenstofflöslichkeit und damit die Härte in der expandierten Austenitzone. Zusätzlich zu ihrem Einfluss auf die C-Aufnahme hat die chemische Zusammensetzung einen Einfluss darauf, welche Karbide sich bilden, sobald die C-Löslichkeit im expandierten Austenit überschritten wird. Ein hoher Ni-Gehalt in Kombination mit einem hohen $\mathrm{Cr}$-Gehalt verhindert die Bildung von Fe-basiertem Hägg-Karbid, $\mathrm{M}_{5} \mathrm{C}_{2}$, und begünstigt die Bildung des thermodynamisch stabileren Cr-basierten Karbids $\omega-\mathrm{M}_{7} \mathrm{C}_{3}$. Darüber hinaus scheint ein höherer Gehalt an Legierungselementen, die Zwischengitteratome binden, eine größere Tiefe des expandierten Austenitgehäuses während der Niedertemperatur-Aufkohlung zu fördern. Ähnlich wie bei niedrigtemperaturenitrierten autenitischen Stählen wird die durch Zwischengitteratome verursachte Gitterausdehnung elastoplastisch kompensiert, was sich durch Gleitlinien und Gitterrotation im oberflächennahen Bereich der expandierten Austenitzone zeigt. Bei einem höheren Kohlenstoffgehalt tritt eine stärkere plastische Verformung auf, was dazu beitragen kann, dass $\omega-M_{7} C_{3}$ gegenüber $M_{5} C_{2}$ bevorzugt gebildet wird. 
Acknowledgement

Philipp Schuler, Nova Swiss (Switzerland), kindly provided the Kolsterized specimens.

\section{Danksagung}

Pilipp Schuler, Nova Swiss (Schweiz), stellte freundlicherweise die kolsterisierten Proben zur Verfügung.

\section{References}

1. Sun, $Y$; Li, X; Bel, T.: Low temperature plasma carburising of austenitic stainlesssteels for improved wear and corrosion resistance. Surf. Eng. 15 (1999) 1, pp. 4954, DOI:10.1179/026708499322911647

2. Garcia Molleja, J.; Nosei, L.; Ferron, J.; Bemporad, E.; Lesage, J.; Chicot, D.; Feugeas, J: Characterization of expanded austenite developed on AISI 316L stainless steel by plasma carburization. Surf. Coatings Technol. 204 (2010) 23, pp. 3750-3759, DOI:10.1016/j.surfcoat.2010.04.036

3. Li, C. X.; Bell, T.: Corrosion properties of active screen plasma nitrided 316 austenitic stainless steel. Corros. Sci. 46 (2004) 6, pp. 1527-1547, DOI:10.1016/j.corsci. 2003.09.015

4. Fossati, A.; Borgioli F.; Galvanetto, E.; Bacci, T.: Corrosion resistance properties of glow-discharge nitrided AISI 316L austenitic stainless steel in $\mathrm{NaCl}$ solutions. Corros. Sci. 48 (2006) 6, pp. 1513-1527, DOI:10.1016/j.corsci.2005.06.006

5. Martin, F. J.; Natishan, P. M.; Lemieux, E. J.; Newbauer, T. M.; Rayne, R. J.; Bayles, R. A.; Kahn, H.; Michal, G. M.; Ernst, F.; Heuer, A. H.: Enhanced corrosion resistance of stainless steel carburized at low temperature. Metall. Mater. Trans. A Phys. Metall. Mater. Sci., 40 (2009) 8, pp. 1805-1810, DOI:10.1007/s11661-009-9924-Z

6. Litton, F. B.; Morris, A. E.: Carburization of type 316L stainless steel in static Sodium. J. Less-Common Met. 22 (1970) 1, pp. 71-82, DOI:10.1016/0022-5088(70)90177-3

7. Brink, B. K.; Stahl, K.; Christiansen, T. L.; Frandsen, C.; Hansen, M. F.; Somers, M. A. J.: Composition-dependent variation of magnetic properties and interstitial ordering in homogeneous expanded austenite. Acta Mater. 106 (2016) pp. 32-39, DOI:10.1016/j.actamat.2015.12.043

8. Christiansen, T. L.; Stahl, K.; Brink, B. K.; Somers, M. A. J.: On the Carbon Solubility in Expanded Austenite and Formation of Hagg Carbide in AISI 316 Stainless Steel. Steel Res. Int. 87 (2016) 11, pp. 1395-1405, DOI:10.1002/srin.201500415

9. Christiansen, T.; Somers, M. A. J.: Low temperature gaseous nitriding and carburising of stainless steel. Surf. Eng. 21 (2005) 5-6, pp. 445-455, DOI:10.1179/ $174329405 \times 68597$

10. Williamson, D. L.; Davis, J. A.; Wilbur, P. J.: Effect of austenitic stainless steel composition on low-energy, high-flux, nitrogen ion beam processing. Surf. Coatings Technol. 103-104 (1998) pp. 178-184, DOI:10.1016/S0257-8972(98)00389-2

11. Fernandes, F. A. P.; Christiansen, T. L.; Somers, M. A. J.: Low temperature gaseous nitriding of a stainless steel containing strong nitride formers. Heat Treat. Surf. Eng. - Proc. Heat Treat. Surf. Eng. HTSE 2013, 16.-18.05.13, Chennai, India, ASM Int. Chennai Chapter, Chennai, India, 2013, pp. 473-482

12. Christiansen, T.; Somers, M. A. J.: Controlled dissolution of colossal quantities of nitrogen in stainless steel. Metall. Mater. Trans. A 37 (2006) 3, pp. 675-682, DOI:10.1007/s11661-006-0039-5

13. Hummelsh, T. S.; Christiansen, T. L.; Somers, M. A. J.: Lattice expansion of carbonstabilized expanded austenite. 63 (2010) 7, pp. 761-763, DOI:10.1016/j.scriptamat.2010.05.031

14. Jegou, S.; Christiansen, T. L.; Klaus, M.; Genzel, C.; Somers, M. A. J.: Determination of composition, residual stress and stacking fault depth profiles in expanded austenite with energy-dispersive diffraction. Thin Solid Films 63 (2013) 7, pp. 71-76, DOI:10.1016/j.tsf.2012.06.029

15. Fernandes, F. A. P.; Christiansen, T. L.; Winther, G.; Somers, M. A. J.: On the determination of stress profiles in expanded austenite by grazing incidence X-ray diffraction and successive layer removal. Acta Mater. 94 (2015), pp. 271-280, DOI:10.1016/j.actamat.2015.04.040

16. Bottoli, F.; Christiansen, T. L.; Winther, G.; Somers, M. A. J.: Effect of Plastic Prestraining on Residual Stress and Composition Profiles in Low-Temperature Surface-Hardened Austenitic Stainless Steel. Metall. Mater. Trans. A. 47 (2016) 8, pp. 4001-4011, DOI:10.1007/s11661-016-3586-4
17. Fernandes, F. A. P.; Christiansen, T. L.; Winther, G.; Somers, M. A. J.: Measurement and tailoring of residual stress in expanded austenite on austenitic stainless steel. Mater. Sci. Eng. A. 701 (2017), pp. 167-173, DOI:10.1016/j.msea.2017.06.082

18. Peng, Y.; Liu, Z.; Jiang, Y.; Wang, B.; Gong, J.; Somers, M. A. J.: Experimental and numerical analysis of residual stress in carbon-stabilized expanded austenite. Scr. Mater. 157 (2018), pp. 106-109, DOI:10.1016/j.scriptamat.2018.08.006

19. Jespersen, F. N.; Hattel, J. H.; Somers. M. A. J.: Modelling the evolution of composition-and stress-depth profiles in austenitic stainless steels during low-temperature nitriding. Model. Simul. Mater. Sci. Eng. 24 (2016) 2, p. 025003, DOI:10.1088/09650393/24/2/025003

20. Fewell, M.; Mitchell, D. R.; Priest, J.; Short, K.; Collins, G.: The nature of expanded Austenite. Surf. Coatings Technol. 131 (2002) 1-3, pp. 300-306, DOI:10.1016/ s0257-8972(00)00804-5

21. Templier, C.; Stinville, J. C.; Villechaise, P.; Renault, P. O.; Abrasonis, G.; Riviere, J. P.; Martinavičius, A.; Drouet, M.: On lattice plane rotation and crystallographic structure of the expanded austenite in plasma nitrided AISI 316L steel. Surf. Coatings Technol. 204 (2010) 16-17, pp. 2551-2558, DOI:10.1016/j.surfcoat.2010.01.041

22. Somers, M. A. J.; Kucukyildiz, O. C.; Ormstrup, C. A.; Alimadadi, H. ; Hattel, J. H.; Christiansen, T. L.; Winther, G.: Residual Stress in Expanded Austenite on Stainless Steel; Origin, Measurement, and Prediction. Mater. Perform. Charact. 7 (2018) 4, pp. 693-716, DOI:10.1520/mpc20170145

23. Christiansen, T.; Somers, M. A. J.: Decomposition kinetics of expanded austenite with high nitrogen contents. Int. J. Mater. Res. 97 (2006) 1, pp. 79-88, open access

24. Sun, Y.; Li, X; Bell, T.: Structural characteristics of low temperature plasma carburised austenitic stainless steel. Mater. Sci. Technol. 15 (1999) 10, pp. 1171-1178, DOI:10.1179/026708399101505077

25. Sun, Y.; Chin, L. Y.: Residual stress evolution and relaxation in carbon S phase layers on AISI 316 austenitic stainless steel. Surf. Eng., 18 (2002) 6, pp. 443-447, DOI:10.1179/026708402225010029

26. Christiansen, T. L.; Somers, M. A. J.: Stress and composition of carbon stabilized expanded austenite on stainless steel. Metall. Mater. Trans. A 40 (2009) 8, pp. 1791-1798, DOI:10.1007/s11661-008-9717-9

27. Peng, Y.; Chen, C; Li, X.; Gong, J.; Jiang, Y.; Liu, Z.: Effect of low-temperature surface carburization on stress corrosion cracking of AISI 304 austenitic stainless steel. Surf. Coatings Technol. 328 (2017), pp. 420-427, DOI:10.1016/j.surfcoat.2017.08.058

28. Peng, Y.; Gong, J.; Christiansen, T. L.; Somers, M. A. J.: Surface modification of Co$\mathrm{Cr}$-FeNi high entropy alloy by low-temperature gaseous carburization. Mater. Lett. 28 (2021), p. 128896, DOI:10.1016/j.matlet.2020.128896

29. Somers, M. A. J.; Christiansen, T. L.: Low temperature surface hardening of stainless steel. Woodhead Publishing Limited, Sawston, UK, 2015, pp. 557-579, DOI:10.1533/9780857096524.4.557

30. Hielscher, R.; Schaeben, H.; Siemes, H.: Orientation distribution within a single hematite Crystal. Math. Geosci. 42 (2010) 4, pp. 359-375, DOI:10.1007/s11004010-9271-Z

31. Ernst, F.; Cao, Y.; Michal, G. M.; Heuer, A. H.: Carbide precipitation in austenitic stainless steel carburized at low temperature. Acta Mater. 55 (2007) 6, pp. 18951906, DOI:10.1016/j.actamat.2006.09.049

32. Ernst, F.; Li, D.; Kahn, H.; Michal, G. M.; Heuer, A. H.: The carbide M7C3 in lowtemperature-carburized austenitic stainless steel. Acta Mater. 59 (2011) 6, pp. 2268-2276, DOI:10.1016/j.actamat.2010.11.058

33. Maistro, G.; Yao, Y.; Klement, U.; Nyborg, L.; Cao, Y.: On surface carbides in lowtemperature carburized austenitic stainless steels. Mater. Charact. 167 (2020), p. 110462, DOI:10.1016/j.matchar.2020.110462 
34. Maistro, G.; Kante, S.; Nyborg, L.; Cao, Y.: Low-temperature carburized highalloyed austenitic stainless steels in PEMFC cathodic environment. Surf. Inter. 2 (2021), p. 101093, DOI:10.1016/j.surfin.2021.101093

35. Maistro, G.; Oikonomou, C.; Rogstrom, L.; Nyborg, L.; Cao, Y.: Understanding the microstructure-properties relationship of low-temperature carburized austenitic stainless steels through EBSD analysis. Surf. Coatings Technol. 322 (2017), pp. 141-151, DOI:10.1016/j.surfcoat.2017.05.036

36. Somers, M. A. J.: Development of Compound Layer and Diffusion Zone during Nitriding and Nitrocarburizing of Iron and Steels. Compr. Mater. Process., 13th Vol., M. S. J. Hashmi (ed.), Elsevier, Amsterdam, Netherlands, 2014, pp. 413-437, DOI:10.1016/B978-0-08-096532-1.01215-2

37. Ernst, F.; Avishai, A.; Kahn, H.; Gu, X.; Michal, G. M.; Heuer, A. H.: Enhanced carbon diffusion in austenitic stainless steel carburized at low temperature. Metall. Mater. Trans. A 40 (2009) 8, pp. 1768-1780, DOI:10.1007/s11661-009-9854-9

38. Christiansen, T.; Dahl, K. V.; Somers, M.A. J.: Nitrogen diffusion and nitrogen depth profiles in expanded austenite: Experimental assessment, numerical simulation and role of stress. Mater. Sci. Technol. 24 (2008) 2, pp. 159-167, DOI:10.1179/026708307X232901
39. Stinville, J. C.; Cormier, J.; Templier, C.; Villechaise, P.: Modeling of the lattice rotations induced by plasma nitriding of 316 polycrystalline stainless steel. Acta Mater. 83 (2015), pp. 10-16, DOI:10.1016/j.actamat.2014.09.052

40. Kucukyildiz, O. C.; Sonne, M. R.; Thorborg, J.; Somers, M. A. J. ; Hattel, J. H.: Thermochemical-mechanical simulation of low temperature nitriding of austenitic stainless steel; inverse modelling of surface reaction rates. Surf. Coatings Technol. 381 (2020), p. 125145, DOI:10.1016/j.surfcoat.2019.125145

\section{Bibliography}

DOI:10.1515/htm-2022-0001

HTM J. Heat Treatm. Mat.

77 (2022) 1; page 3-15

(C) 2022 Walter de Gruyter GmbH, Berlin/Boston, Germany ISSN 1867-2493, e-ISSN 2194-1831 